\title{
A sexuality and relationship training program for women with intellectual disabilities:
}

\section{A social story approach}

\author{
Juan Bornman $^{1, *}$ and Liezel Rathbone ${ }^{1}$ \\ ${ }^{1}$ Centre for Augmentative and Alternative Communication (CAAC), Communication Pathology Building, \\ University of Pretoria \\ *Author for correspondence: Juan.Bornman@up.ac.za
}

\begin{abstract}
A multi-method study design involving three different phases was used to develop four social stories that could be used as part of a sexuality and relationship training program for women with intellectual disabilities. Phase 1 entailed a systematic review of the literature and results indicate that social stories provide a suitable methodology for teaching socially desirable responses related to sexuality and relationships. Phase 2 entailed a focus group with women with intellectual disabilities and results showed that they wanted more information about different types of relationships, including romantic relationships. They also wanted to understand what types of behaviour (e.g. different types of greetings) were appropriate for the different types of relationships. Next, four social stories were written based on the results of these two phases. Finally, these four social stories were implemented in Phase 3 with ten caregivers of women with intellectual disabilities in order to evaluate the appropriateness of the stories. Results showed that three of the four social stories were appropriate, and that one required re-writing as it was not appropriate for the specific context, as women at that facility did not have the opportunity to go on dates. A suggestion was made that the story be re-written to reflect romantic relationships as opposed to dating.
\end{abstract}

\section{Keywords}

Caregivers; Intellectual Disability; Relationship; Social stories ; Women

\section{Introduction}

Women with intellectual disabilities are increasingly requesting appropriate information related to sexuality and relationships. Therefore it is unfortunate that these women are frequently excluded from the realm of sexuality education, as the form and content of existing training programs are often not accessible for this 
population. When they are included, however, it is most often reactive rather than proactive, commonly addressed only after women with intellectual disabilities have become sexually active (Boehning, 2006; Gerhardt, 2006). Adopting a reactive approach rather than a proactive one increases the likelihood of women with intellectual disabilities staying uninformed or being misinformed. This increases their risk of being sexually abused and exploited, contracting a sexually transmitted disease, compromised self-advocacy skills, inappropriate socio-sexual behaviour as well as social exclusion and isolation. Sexuality education is often unacknowledged and untaught by many caregivers, resulting in these skills being learned incidentally by the women with intellectual disabilities, typically through interactions with peers at breakfast, lunch, or supper time (Gougeon, 2009). In addition, these women are often in segregated adult facilities where they have no opportunities of interacting with non-disabled peers. Furthermore, women with intellectual disabilities are less likely to participate in extra-curricular activities and are not often employed part-time, two prime areas that exclude them from peer interaction and social integration which could act as a source of sexuality instruction. Unfortunately, the cumulative effects of negative social attitudes to the sexuality of women with intellectual disabilities as well as restrictive social perspectives on the sexuality of women in general (Fitzgerald \& Withers, 2011) hinder this process. On the one hand the sexual needs of these women are often ignored, curtailed or actively denied by professionals, their primary caregivers or parents as well as the general community (Morales, Lopez \& Mullet, 2011; Szollos \& McCabe, 1998). On the other hand, over-protective attitudes toward women with intellectual disabilities typically stem from the desire to protect them from unpleasant experiences, although it is these very experiences which help them grow (Deeley, 2002).

Therefore, attention needs to be paid to what women with intellectual disabilities want in terms of support on sexuality education, by asking the women themselves, as well as asking caregivers for their perspectives. For example, when asking 21 young women with intellectual disabilities about sexuality they stated that their main interests were related to friendship and dating (Bleazard, 2010). Finding the means to empower women with intellectual disabilities to acknowledge, welcome and take control of their own sexuality should be seen as a high priority.

One of the reasons why women with intellectual disabilities find it difficult to learn about their own sexuality is the training methods used to address the complex and emotionally laden construct of their own sexuality knowledge. Research indicates that within the disability field, women with intellectual disabilities are the silent voices in the knowledge of their sexuality (Hanna \& Rogovsky, 1991). These aspects complicate matters when offering training about sexuality to women with intellectual disabilities. However, sexuality 
cannot be ignored. The lack of training of and guidance to these women may contribute to misunderstandings and to socially inappropriate behaviour. The attitudes and knowledge of caregivers who have continuous contact and interaction with these women, impact on how guidance in terms of sexuality is provided. For example, if they have more conservative attitudes about the sexuality of women with intellectual disabilities and feel that sexuality is not an important topic they might brush it aside during caregiving. However, all women, including those with an intellectual disability, have the right and need to express their feelings related to sexuality. The right to be free from sexual exploitation and harm is also of critical importance.

Social stories have been proven effective as strategies to change target behaviour as they provide social information to highlight and teach appropriate, as opposed to inappropriate, social behaviour (Gray, 2003).

These stories are typically short and custom-written to describe an activity (for example, hugging), as well as the anticipated behaviour associated with it (for example, who to hug and when to hug). They attempt to demystify complex social behaviour which are typically governed by various unwritten and unspoken rules and non-verbal cues, for example, arms folded across the chest means "I don't want a hug”. In social stories, social situations and appropriate responses are addressed in a non-threatening way (Del-Valle, McEachern \& Chambers, 2001). The use of social stories in sexuality training programs, specifically for individuals with intellectual disabilities who may benefit from overt social rules, therefore appears to be a potentially advantageous intervention tool. Earlier research, although not social-story specific, also showed that the use of specific scenarios (as found in social stories) yielded the most favourable results on exploring results in exploring sexuality for individuals with intellectual disabilities (Evans, McGuire, Healy, \& Carley, 2009).

The fact that social stories provide a concrete method for teaching a skill, using a visual medium, such as pictures, is a strength for many individuals with intellectual disabilities, particularly in cases when they have limited or no literacy skills. Furthermore, they is easy to implement (Moyes, 2001) which heightens its suitability for specific context, such as ones where caregivers at adult facilities may also have low literacy levels.

Therefore the main aim of this study was to develop four social stories that could be used as part of a sexuality and relationship training program for women with intellectual disabilities.

\section{Methods}

A multi-method study design involving three different phases was used (De Hoogh \& Den Hartog, 2008), in order to address the main aim of the research. In Phase 1, a systematic search of currently published 
literature regarding social stories as an intervention tool for individuals with intellectual disabilities was done. In Phase 2 a focus group was conducted with women with intellectual disabilities was done in order to make their own voices heard the aspects that they thing should be addressed in sexuality and relationship training. In Phase 3, caregivers of women with intellectual disability were trained in the implementation of social stories. Each of the three phases will be discussed in sequence.

\section{Phase 1:}

The main aim of Phase 1 was to conduct a systematic search of published studies on the use of social stories as an intervention tool to modify, change or decrease inappropriate social behaviour related to sexuality and relationship components in individuals with intellectual impairments.

A systematic literature search was done, using the search term *social stor* in combination with search terms such as "sex*”, "education", "intellectual" and "disabil*”. The truncation symbol (*) was used as relevant in the individual databases to maximise the search results. Five databases were searched, namely PsycINFO; Educational Resources Information Clearinghouse (ERIC); Science direct; Taylor and Francis; and EBSCO host. The search results were further delimited to peer review journal status and year of publication (19972014). In addition, hand-search documents were included and examined, based on reference lists of retrieved documents cited and unpublished reviews related to social stories, disability and sexuality education.

A total of 14 manuscripts were found. Six of these were excluded on the abstract level for the following reasons: one dealt only with task analysis for teaching menstrual care (Klett \& Turan, 2012); one dealt with preschoolers with autism enrolled in full-inclusion kindergarten classrooms (Chan \& O’Reilly, 2008); one dealt with children between three and four years of age who had specific language impairments (Pettigrew, 1998); one dealt with individuals with learning disabilities (Kalyva \& Agaloitis, 2008); one only dealt with changing problematic lunchtime behaviour related to independently entering the dining-room hall (Toplis \& Hadwin, 2006); and one with decreasing disruptive behaviour of children with autism (Ozdemir, 2008). The remaining eight papers were read at full-text level and are summarised in Table 1.

The literature review showed that social stories can be an effective intervention tool when attempting to change inappropriate or problematic behaviour. However, no published studies could be identified from the literature review where social stories were used in sexuality education for adults with intellectual disabilities. Most of the studies had been done on children (albeit with different ages) who had an autism diagnosis. 
Table 1 Literature review of social stories in chronological order, starting with the most recent papers $(\mathrm{N}=8)$

\begin{tabular}{|c|c|c|c|c|c|}
\hline Authors \& date & Aim & Participants & $\begin{array}{l}\text { Use of social story } \\
\text { strategy }\end{array}$ & Significance & Implication for current study \\
\hline $\begin{array}{l}\text { Graetz, Mastropieri } \\
\text { \& Scruggs, } \\
2009 .\end{array}$ & $\begin{array}{l}\text { To determine the effect } \\
\text { of a modified social } \\
\text { story on inappropriate } \\
\text { social behaviour. }\end{array}$ & $\begin{array}{l}\text { Three adolescents with } \\
\text { moderate autism between } \\
12 \text { and } 15 \text { years. }\end{array}$ & $\begin{array}{l}\text { Individualised stories } \\
\text { were used. }\end{array}$ & $\begin{array}{l}\text { Individualised stories were } \\
\text { created for each participant; } \\
\text { intervention immediately } \\
\text { improved the behaviour of two of } \\
\text { the participants; improvement } \\
\text { was maintained. }\end{array}$ & $\begin{array}{l}\text { Positive outcomes of desired } \\
\text { behaviour; actual use of coloured } \\
\text { photographs. } \\
\text { Social stories adhered to guidelines } \\
\text { regarding the ratio of one directive } \\
\text { sentence to two to five descriptive or } \\
\text { perspective sentences (Gray, 1995). }\end{array}$ \\
\hline $\begin{array}{l}\text { Mancil, Haydon \& } \\
\text { Whitby, } \\
2009 .\end{array}$ & $\begin{array}{l}\text { To compare social story } \\
\text { presentations in two } \\
\text { formats. }\end{array}$ & $\begin{array}{l}\text { Three elementary children } \\
\text { with autism between } 10 \\
\text { and } 12 \text { years. }\end{array}$ & $\begin{array}{l}\text { Comparing social } \\
\text { stories in PowerPoint } \\
\text { (PPT) and paper-based } \\
\text { format. }\end{array}$ & $\begin{array}{l}\text { Frequency of problem behaviour } \\
\text { decreased; outcomes slightly } \\
\text { better for PPT story than for } \\
\text { paper format; PPT format was } \\
\text { more easily implemented; } \\
\text { children preferred PPT format. }\end{array}$ & $\begin{array}{l}\text { PPT formatted story worked } \\
\text { effectively. Additional visual stimuli } \\
\text { supported individuals and resulted in } \\
\text { desired outcomes. Use social stories in } \\
\text { PPT format in the present study. }\end{array}$ \\
\hline $\begin{array}{l}\text { Quimbach, Lincoln, } \\
\text { Feinberg-Gizzo, } \\
\text { Ingersoll \& } \\
\text { Andrews, } \\
2009 .\end{array}$ & $\begin{array}{l}\text { To increase social skills } \\
\text { through the use of social } \\
\text { story interventions. }\end{array}$ & $\begin{array}{l}42 \text { children with autism } \\
\text { between seven and } 14 \\
\text { years. }\end{array}$ & $\begin{array}{l}\text { Social stories were used } \\
\text { for game-playing skills. }\end{array}$ & $\begin{array}{l}\text { Individuals with extremely low } \\
\text { verbal comprehension skills } \\
\text { (based on the WISC-IV) may not } \\
\text { benefit from social story } \\
\text { interventions that do not include } \\
\text { pictures or other concomitant } \\
\text { treatment strategies. }\end{array}$ & $\begin{array}{l}\text { The ability of directive sentences in } \\
\text { social stories to prime behaviour in } \\
\text { specific contexts describes the } \\
\text { importance of providing cues as a } \\
\text { conversational support. }\end{array}$ \\
\hline $\begin{array}{l}\text { Wang \& Spillane, } \\
2009 .\end{array}$ & $\begin{array}{l}\text { To provide a synthesis } \\
\text { of published research }\end{array}$ & $\begin{array}{l}18 \text { children and adolescents } \\
\text { with autism spectrum }\end{array}$ & $\begin{array}{l}\text { Social skills stories } \\
\text { were used to determine }\end{array}$ & $\begin{array}{l}\text { Six of these } 38 \text { studies included } \\
\text { in the review dealt with social }\end{array}$ & $\begin{array}{l}\text { Improved social skills are more likely } \\
\text { to result in an individual being }\end{array}$ \\
\hline
\end{tabular}




\begin{tabular}{|c|c|c|c|c|c|}
\hline Authors \& date & Aim & Participants & $\begin{array}{l}\text { Use of social story } \\
\text { strategy }\end{array}$ & Significance & Implication for current study \\
\hline & $\begin{array}{l}\text { between } 1999 \text { and } 2009 \\
\text { on interventions to } \\
\text { increase social skills; } \\
\text { evaluate if given } \\
\text { intervention meets } \\
\text { criteria for evidence- } \\
\text { based practice. }\end{array}$ & disorder. & $\begin{array}{l}\text { if they met the criteria } \\
\text { for evidence-based } \\
\text { practice. }\end{array}$ & $\begin{array}{l}\text { stories to teach social skills. } \\
\text { Social stories were one of the } \\
\text { intervention types that met all the } \\
\text { criteria for evidence-based } \\
\text { practices. The percentage of non- } \\
\text { overlapping data points) for two } \\
\text { of the six social stories } \\
\text { intervention studies demonstrated } \\
\text { high effectiveness. }\end{array}$ & $\begin{array}{l}\text { accepted in integrated settings, to live } \\
\text { independently and to work in } \\
\text { integrated settings. }\end{array}$ \\
\hline $\begin{array}{l}\text { Tarnai } \\
\& \text { Wolfe, } \\
2008 .\end{array}$ & $\begin{array}{l}\text { To investigate the } \\
\text { components that make } \\
\text { social stories a } \\
\text { promising method for } \\
\text { intervention, and to } \\
\text { discuss the implications } \\
\text { of using social stories } \\
\text { for sexuality education. }\end{array}$ & $\begin{array}{l}\text { A survey was done of } \\
\text { parents and professionals } \\
\text { on sexual behaviour of } \\
\text { persons with autism or } \\
\text { pervasive developmental } \\
\text { disorder from } 1970 \text { to } \\
2000 \text {. }\end{array}$ & $\begin{array}{l}\text { Social stories were used } \\
\text { as components for } \\
\text { interventions and the } \\
\text { implications of utilising } \\
\text { them for sexuality } \\
\text { education, in particular, } \\
\text { instructional use. }\end{array}$ & $\begin{array}{l}\text { Social stories can be used in a } \\
\text { general way to prepare } \\
\text { individuals for changes and } \\
\text { unusual situations as a part of } \\
\text { going through stages of sexual } \\
\text { development, or they can be } \\
\text { written in reaction to evolved } \\
\text { problematic situations. }\end{array}$ & $\begin{array}{l}\text { Typical sexuality education programs } \\
\text { for individuals with intellectual } \\
\text { disabilities may lack components that } \\
\text { address the unique social skills of } \\
\text { women with intellectual disabilities. }\end{array}$ \\
\hline $\begin{array}{l}\text { Quilty, } \\
2007 .\end{array}$ & $\begin{array}{l}\text { To determine if } \\
\text { paraprofessionals can be } \\
\text { taught to write and } \\
\text { implement social } \\
\text { stories. }\end{array}$ & $\begin{array}{l}\text { Three children between six } \\
\text { and } 10 \text { years, and three } \\
\text { paraprofessionals } \\
\text { participated in pairs. }\end{array}$ & $\begin{array}{l}\text { Social stories were used } \\
\text { for paraprofessionals as } \\
\text { an effective tool for } \\
\text { interventions. }\end{array}$ & $\begin{array}{l}\text { Paraprofessional can be taught } \\
\text { how to write and implement } \\
\text { social stories; children's } \\
\text { problems in behaviour are } \\
\text { reduced. }\end{array}$ & $\begin{array}{l}\text { Teaching paraprofessionals to write } \\
\text { social stories to address particular } \\
\text { behaviour and to implement social } \\
\text { stories can have a positive effect on } \\
\text { behavioural change. }\end{array}$ \\
\hline Ali \& Frederickson, & To review research on & 46 children between 2 and & Investigating the & One study involved a training & The intervention was effective with \\
\hline
\end{tabular}




\begin{tabular}{|c|c|c|c|c|c|}
\hline Authors \& date & Aim & Participants & $\begin{array}{l}\text { Use of social story } \\
\text { strategy }\end{array}$ & & Implication for current study \\
\hline 2006. & $\begin{array}{l}\text { social stories published } \\
\text { between } 1994 \text { and } 2004 .\end{array}$ & $\begin{array}{l}15 \text { years. } \\
\text { Children between three and } \\
15 \text { years old were studied. }\end{array}$ & $\begin{array}{l}\text { evidence base of social } \\
\text { stories. }\end{array}$ & $\begin{array}{l}\text { program spread over two half } \\
\text { days, attesting to the } \\
\text { effectiveness of relative short- } \\
\text { term training. Two educational } \\
\text { psychologists ran the program for } \\
\text { mainstream teachers, learning- } \\
\text { support assistants and parents / } \\
\text { carers of } 15 \text { children with ASD, } \\
\text { two with learning difficulties, one } \\
\text { with Tourette's syndrome and one } \\
\text { with semantic pragmatic } \\
\text { difficulties. }\end{array}$ & children with autism. \\
\hline $\begin{array}{l}\text { Del Valle, } \\
\text { McEachern \& } \\
\text { Chambers, } \\
2001 .\end{array}$ & $\begin{array}{l}\text { To improve social } \\
\text { functioning by } \\
\text { addressing appropriate } \\
\text { behaviour in social } \\
\text { situations and } \\
\text { developing problem- } \\
\text { solving skills. }\end{array}$ & $\begin{array}{l}\text { Narrative story-telling: } \\
\text { listening, telling, re-telling } \\
\text { social stories. }\end{array}$ & $\begin{array}{l}\text { Developing problem- } \\
\text { solving skills; } \\
\text { addressing social } \\
\text { situations using social } \\
\text { stories. }\end{array}$ & $\begin{array}{l}\text { Social stories were effective in } \\
\text { changing behaviour and therefore } \\
\text { could also be used to address } \\
\text { inappropriate behaviour related to } \\
\text { sexuality and social skills. }\end{array}$ & $\begin{array}{l}\text { Personalising social skills training. } \\
\text { Modelling social stories appropriate } \\
\text { for social skill behaviour. For the } \\
\text { women with intellectual disabilities } \\
\text { who cannot read, social stories can be } \\
\text { audio or video taped. Social stories } \\
\text { were effective in changing behaviour } \\
\text { and therefore could also be used to } \\
\text { address inappropriate behaviour } \\
\text { related to sexuality and social skills. }\end{array}$ \\
\hline
\end{tabular}


However, given the effectiveness of social stories to change behaviour, and the focus on sexuality and relationship education in adults with intellectual disabilities, social stories seem to be a suitable methodology.

\section{Phase 2}

The main aim of Phase 2 was to provide women with intellectual disabilities with the opportunity to share their knowledge and experiences about their sexuality and relationships, and to make their voices heard. Research has shown that including participants from the primary stakeholder group (in this case women with intellectual disabilities themselves) provides researchers with increased insights, such as how the disability influences their sexuality; how they express their sexuality and how they came to learn about sexuality (Bernert, 2011; Bleazard, 2010; Miodrag, 2004). Therefore, a paradigm shift is needed in research to acknowledge this involvement, so that the discourse that involves the primary stakeholder group can be encouraged, rather than the traditional methods of using proxy participants such as caregivers or parents (Bernert, 2011).

Four specific questions were asked during the focus groups, namely; i) What do you think is important in an intimate relationship? ii) What do you think is important to include in a sexuality and relationship training program? For example, "I am not allowed to have an intimate relationship with my uncle because he is a relative, but I can have an intimate relationship with [name]". Another example is when a stranger visits the centre to do business, one of the residents cannot just approach the person and hug and kiss him or her. So what do you think is important to be in a program you think the residents should learn that could improve their behaviour? iii) What do you want to learn more about? and iv) What do you think should not be included in such a program? What would you prefer not to talk about?

\section{Participants}

Only female participants with a chronological age above 18 years were included, as they have a double predisposition of being the victims of abuse, because of the fact that they are women, and the fact that they are disabled (Lafferty, McConkey, \& Taggart, 2012). Their heightened vulnerability makes them the focus of this research. Their biographic information is shown in Table 2.

It is evident from Table 2 that all the participants stated that they currently have a boyfriend or that they have previously had one. In addition, the training of sexuality education is reflected by only six of the participants. 
Table 2: Biographic information on women with intellectual disabilities (Phase 2) $(\mathrm{N}=10)$

\begin{tabular}{|c|c|c|c|c|c|c|c|c|c|c|}
\hline Participants & 2.1 & 2.2 & 2.3 & 2.4 & 2.5 & 2.6 & 2.7 & 2.8 & 2.9 & 2.10 \\
\hline Aetiology & Acquired & Genetic & Genetic & Genetic & Acquired & Genetic & $\begin{array}{l}\text { Develop- } \\
\text { mental }\end{array}$ & Genetic & Acquired & $\begin{array}{l}\text { Develop- } \\
\text { mental }\end{array}$ \\
\hline Age & 51 years & 55 years & 40 years & 25 years & 23 years & 45 years & 47 years & 42 years & 45 years & 48 years \\
\hline Language & Afrikaans & English & Afrikaans & Afrikaans & English & Afrikaans & Afrikaans & Afrikaans & Afrikaans & Afrikaans \\
\hline Education & Grade 5 & Grade 8 & Unknown & Group 7 & Grade 9 & Unknown & Grade 8 & Level 5 & Level 2 & Grade 10 \\
\hline $\begin{array}{l}\text { Religious } \\
\text { affiliation }\end{array}$ & Christian & Christian & Christian & Christian & Christian & Christian & Christian & Christian & Christian & Christian \\
\hline Boyfriend currently & Yes & No & No & Yes & Yes & Yes & No & Yes & Yes & Yes \\
\hline Boyfriend before & Yes & Yes & Yes & Yes & Yes & Yes & Yes & Yes & No response & No \\
\hline $\begin{array}{l}\text { Formal sex } \\
\text { education }\end{array}$ & No & No & Yes & Yes & Yes & Yes & Yes & No & No & Yes \\
\hline If yes, by whom? & $\mathrm{n} / \mathrm{a}$ & $\mathrm{n} / \mathrm{a}$ & Mother & Clinic & Mother, school & Teacher & Mother & $\mathrm{n} / \mathrm{a}$ & $\mathrm{n} / \mathrm{a}$ & Mother \\
\hline $\begin{array}{l}\text { Focus of sex } \\
\text { Education program }\end{array}$ & No response & No respons & General & $\begin{array}{l}\text { Use condoms to } \\
\text { be safe and } \\
\text { prevent HIV, } \\
\text { have safe sex } \\
\text { and prevent from } \\
\text { having babies }\end{array}$ & $\begin{array}{l}\text { Safety } \\
\text { HIV/Aids } \\
\text { Babies } \\
\end{array}$ & Use condoms & $\begin{array}{l}\text { Does not } \\
\text { spend time } \\
\text { alone with } \\
\text { boys }\end{array}$ & No response & No response & Conception \\
\hline
\end{tabular}




\section{Method}

A relaxed non-threatening environment was created by providing fruit juice and cupcakes to the participants before commencing with the focus group. The social worker who was familiar to the participants, acted as a co-facilitator and her presence was essential, as she was acquainted with the language difficulties experienced by some of the women with intellectual disabilities. Her presence thus put the women at ease. The focus group was conducted in the mother tongue of the group, namely Afrikaans. Although the participants could not provide written informed consent, assent was explained and obtained from all the participants with the support of picture symbols. Consent was obtained from their legal guardians prior to the focus group.

Confidentiality, voluntary participation, and the fact that they could terminate participation at any point without negative consequences, were also explained with the support of symbols. Participants were informed that the discussions would be audio recorded in order to facilitate accurate transcription by the researcher. Before commencement of the discussion, important concepts were explained by using clips from magazines, for example: friends versus strangers; romantic relationships versus friendships; and public places versus private places. This aided the women's understanding of the concepts. When participants struggled to express themselves or to understand the researcher, questions where rephrased and clarifications given. The focus group session lasted 180 minutes, and was not transcribed verbatim, although an audio recording was made in order to familiarise the participants with the procedure and equipment.

\section{Data analysis}

Thematic analysis was used to analyse the raw data, focusing on themes identified by coding, to discover recurrent patterns.

\section{Results}

Themes represent the women as a collective group and do not include data identifiable to any one particular woman. The women conveyed understanding of their own personal values within a romantic relationship, as well as what their personal needs were. Four themes were extrapolated from the focus group interaction concerning what the women would want from an educational training program regarding sexuality and relationships. These themes were as follows: i) clarifying the difference between a romantic relationship and other types of relationships; ii) clarifying how to behave in a romantic relationship by differentiating between the male and the female role; iii) clarifying how to behave in relationships that are not romantic, for example 
how to greet strangers and iv) clarifying what type of behaviour and conversations are appropriate in different types of relationships

It was evident from the discussion that the women can manage their sexuality in some ways by engaging in healthy sexual behaviour, such as having informed judgment about condom use and contraception. Most of the participants had been in relationships before, or were currently in relationships, and all expressed having an interest in having an intimate, romantic relationship. The importance of companionship, trust and security in relationships were raised by some of the participants. Most of the participants reported some degree of personal and physical intimacy, for example, holding hands, kissing and also intercourse. The sense of selfesteem was mentioned as a gain from such a relationship. Most of the participants had relationships within the residential care setting.

\section{Implications from Phase 1 and Phase 2 for Phase 3}

Supporting women with intellectual disabilities in ways that will enhance their social skills with an effective education program that can address their unique needs, will impact positively on how they understand their own sexuality. Providing them with their right to sexuality education, can also affect their relationships, self-esteem, emotional growth and social behaviour (Bernert, 2011). Four main topics that should be addressed by means of social stories were delineated from the systematic review and the focus group information:

- To teach social boundaries by creating awareness of appropriate and inappropriate touching. This can be done by reinforcing healthy boundaries in relationships; and by creating an awareness of the right to say "no".

- To teach the difference between the concepts "private" and "public" by creating increased awareness of socially acceptable conversations. Sexuality in its totality almost always involves an understanding of public versus private concepts (Couwenhoven, 2007).

- To differentiate between different types of relationships by addressing specific characteristics that make relationships healthy and unhealthy.

- To teach appropriate and acceptable social behaviour in romantic relationships.

All social stories were written according to guidelines developed by Gray (1995; 1997; 2000; 2003), focussed on sentence type:

- A descriptive sentence: This focusses on where the situation occurs, who is involved, what they are doing 
Table 3. A layout of the four social stories

\begin{tabular}{|c|c|c|c|c|}
\hline Guideline & Social Story 1 & Social Story 2 & Social Story 3 & Social Story 4 \\
\hline \multicolumn{5}{|c|}{ 1. A descriptive sentence outlining the following: } \\
\hline $\begin{array}{l}1.1 \text { Where does the } \\
\text { situation occur? }\end{array}$ & $\begin{array}{l}\text { In public } \\
\text { At the mall }\end{array}$ & $\begin{array}{l}\text { Privacy and appropriate } \\
\text { conversations in public and } \\
\text { in the mall }\end{array}$ & $\begin{array}{l}\text { In the community } \\
\text { in the neighbourhood }\end{array}$ & $\begin{array}{l}\text { Green-light places (safe places), for } \\
\text { example, places such as church, the } \\
\text { group home, social groups or } \\
\text { friends of friends } \\
\text { Red-light places (unsafe places), for } \\
\text { example, the mall, the street and } \\
\text { parks }\end{array}$ \\
\hline 1.2. Who is involved? & Caregivers & Strangers & $\begin{array}{l}\text { Family } \\
\text { Friends } \\
\text { Romantic partner } \\
\text { Caregivers } \\
\text { Neighbours } \\
\text { Community helpers } \\
\text { Strangers }\end{array}$ & $\begin{array}{l}\text { Someone special, for example, a } \\
\text { romantic partner }\end{array}$ \\
\hline $\begin{array}{l}1.3 \text { What are they } \\
\text { doing? }\end{array}$ & Hugging & $\begin{array}{l}\text { Bribing } \\
\text { Threatening }\end{array}$ & $\begin{array}{l}\text { Supporting } \\
\text { Respecting } \\
\text { Dating } \\
\text { Assisting } \\
\text { Helping }\end{array}$ & Listening to music \\
\hline $\begin{array}{l}\text { 1.4. Why are they } \\
\text { doing this? }\end{array}$ & $\begin{array}{l}\text { To show love } \\
\text { To show concern }\end{array}$ & $\begin{array}{l}\text { To show that there are different } \\
\text { happy and unhappy secrets }\end{array}$ & $\begin{array}{l}\text { To explain that one has different } \\
\text { types of relationships with different } \\
\text { people }\end{array}$ & $\begin{array}{l}\text { To show that the two partners have } \\
\text { the same interests }\end{array}$ \\
\hline
\end{tabular}




\begin{tabular}{|c|c|c|c|c|}
\hline Guideline & Social Story 1 & Social Story 2 & Social Story 3 & Social Story 4 \\
\hline \multicolumn{5}{|c|}{ 2. A perspective sentence outlining the following: } \\
\hline $\begin{array}{l}.1 \text { Reactions and } \\
\text { feelings of the } \\
\text { individual }\end{array}$ & Hugs make me feel good & $\begin{array}{l}\text { Happy secrets make me feel } \\
\text { happy; unhappy secrets are when } \\
\text { people want to take advantage of } \\
\text { me. }\end{array}$ & $\begin{array}{l}\text { I love and trust my family. } \\
\text { I enjoy being with my friends. } \\
\text { I have sexual feelings for the person I } \\
\text { am in a romantic relationship with. }\end{array}$ & Dating makes me feel excited. \\
\hline $\begin{array}{l}2.2 \text { Reactions and } \\
\text { feelings of other } \\
\text { people }\end{array}$ & $\begin{array}{l}\text { Other people may feel happy } \\
\text { if they are hugged. }\end{array}$ & $\begin{array}{l}\text { Other people might feel happy } \\
\text { when they are surprised with a } \\
\text { happy secret, for example, a } \\
\text { surprise birthday party. } \\
\text { Other people might feel unhappy } \\
\text { when strangers try to bribe them } \\
\text { with gifts or may want to do } \\
\text { sexual things with them. }\end{array}$ & $\begin{array}{l}\text { The other person has sexual feelings } \\
\text { for me if he is in a romantic } \\
\text { relationship with me. } \\
\text { My friends enjoy being with me; } \\
\text { they respect me; they are honest with } \\
\text { me and keep their promises. }\end{array}$ & $\begin{array}{l}\text { The other person feels comfortable } \\
\text { to be with me. }\end{array}$ \\
\hline \multicolumn{5}{|c|}{ 3. Directive sentence outlining the following: } \\
\hline $\begin{array}{l}3.1 \text { What should the } \\
\text { individual do? }\end{array}$ & $\begin{array}{l}\text { I should ask permission before I give } \\
\text { someone a hug? }\end{array}$ & Run! Yell! Tell! & $\begin{array}{l}\text { I should take ownership of who is } \\
\text { allowed to touch me. }\end{array}$ & $\begin{array}{l}\text { The other person is interested in } \\
\text { getting to know me better }\end{array}$ \\
\hline
\end{tabular}


and why.

- A perspective sentence: This focusses on the reactions and feelings of the individual and of the other people.

- $\quad$ A directive sentence: This focusses on what the individual should do (desired behaviour).

Table 3 shows how these sentences were used in the development of the four social stories, which were based on the four themes identified from Phase 1 and Phase 2 of the research as discussed earlier.

Gray $(1995 ; 1997)$ further explained that every directive sentence should be supported by between two and five descriptive sentences and/or perspective sentences, as one of the basic premises of the social story approach is that stories should describe, more than direct. Social Story 1 has a basic sentence ratio of 1:5; Social Story 2 has a ratio of 1:10; Social Story 3 has a ratio of 1:8 and Social Story 4 has a ratio of 2:5. Please see Appendix A for an example of Social Story 1, "All About Hugs".

\section{Phase 3}

Following the development of the social stories, they were implemented at an adult care facility with ten caregivers of women with intellectual disability (Rathbone, 2015). This was done to gauge the appropriateness and usefulness of the stories for women with disabilities, prior to training the women themselves. Caregivers were selected as they play an important role in the education and support of these women, and are thus in a favourable position to evaluate the social stories. Training them (as a secondary stakeholder group) with regards to the social story content and method of implementation, the quality of the stories can be increased resulting in stories that are focussed and relevant.

When implementing the social stories, caregivers at adult care facilities were taught how to read the social story with the women with intellectual disability and were encouraged to point to the accompanying pictures. Emphasis was placed on the fact that each individual should have her own book and should be encouraged to "read" the book as often as she wants to, implying that for some women this may mean reading the words, while for others it may mean looking at the pictures. If the individual is unable to read, the story can be recorded and the individual can be taught to use a recorder and to turn the page when prompted by an auditory signal. They were also informed that the stories might need to be re-read several times. The biographical information of the caregivers who participated in the training, are provided in Table 4. 
Table 4: Biographical information of caregivers who participated in training (Phase 3( $(\mathrm{N}=10)$

\begin{tabular}{|c|c|c|c|c|c|c|c|c|c|c|}
\hline Participant & 3.1 & 3.2 & 3.3 & 3.4 & 3.5 & 3.6 & 3.7 & 3.8 & 3.9 & 3.10 \\
\hline Gender & Female & Female & Female & Female & Female & Female & Male & Male & Female & Female \\
\hline \multirow[t]{2}{*}{ Age } & 41 & 26 & 28 & 34 & 29 & 30 & 24 & 27 & 24 & 30 \\
\hline & Yrs & yrs & yrs & yrs & yrs & yrs & yrs & yrs & yrs & yrs \\
\hline Home language & Sesotho & $\begin{array}{l}\text { Sesotho } \\
\text { isiZulu }\end{array}$ & Sesotho & Sesotho & Other & Sesotho & $\begin{array}{l}\text { Sesotho } \\
\text { isiZulu }\end{array}$ & $\begin{array}{l}\text { Sesotho } \\
\text { isiZulu }\end{array}$ & Sesotho & isiZulu \\
\hline $\begin{array}{l}\text { Religious } \\
\text { affiliation }\end{array}$ & Christian & Christian & None & Christian & Christian & Christian & Christian & Christian & Christian & Christian \\
\hline $\begin{array}{l}\text { Church } \\
\text { attendance }\end{array}$ & $\begin{array}{l}\text { Once a } \\
\text { month }\end{array}$ & $\begin{array}{l}\text { Once a } \\
\text { week }\end{array}$ & $\begin{array}{l}\text { Once a } \\
\text { month }\end{array}$ & $\begin{array}{l}\text { On } \\
\text { special } \\
\text { occasions }\end{array}$ & $\begin{array}{l}\text { On } \\
\text { special } \\
\text { occasions }\end{array}$ & $\begin{array}{l}\text { Once a } \\
\text { week }\end{array}$ & $\begin{array}{l}\text { Once a } \\
\text { month }\end{array}$ & $\begin{array}{l}\text { More than } \\
\text { once a week }\end{array}$ & $\begin{array}{l}\text { Once } \\
\text { a month }\end{array}$ & $\begin{array}{l}\text { Once } \\
\text { a week }\end{array}$ \\
\hline $\begin{array}{l}\text { Years working } \\
\text { at the facility }\end{array}$ & 1 year & 1 month & 3 years & 8 years & 1 month & 4 years & 1 year & 4 years & 1 year & 2 months \\
\hline $\begin{array}{l}\text { Hours working } \\
\text { per day }\end{array}$ & $\begin{array}{l}8 \\
\text { Hours }\end{array}$ & $\begin{array}{l}2 \\
\text { hours }\end{array}$ & 2 hours & $\begin{array}{l}6 \\
\text { hours }\end{array}$ & $\begin{array}{l}8 \\
\text { hours }\end{array}$ & $\begin{array}{l}8 \\
\text { hours }\end{array}$ & $\begin{array}{l}2 \\
\text { hours }\end{array}$ & $\begin{array}{l}8 \\
\text { hours }\end{array}$ & $\begin{array}{l}8 \\
\text { hours }\end{array}$ & $\begin{array}{l}8 \\
\text { hours }\end{array}$ \\
\hline
\end{tabular}


Table 5. Objectives, Materials and Equipment, Procedures, Results and Recommendations following training

\begin{tabular}{|c|c|c|c|c|}
\hline Rationale & Materials \& Equipment & Procedures & Results & Recommendations \\
\hline \multicolumn{5}{|c|}{ Theme 1: Appropriate and inappropriate touching } \\
\hline $\begin{array}{l}\text { The determine the } \\
\text { appropriateness of Social Story } \\
1 \text { aimed at teaching social } \\
\text { boundaries as well as } \\
\text { reinforcing healthy boundaries } \\
\text { within relationships, which } \\
\text { involves knowing the rules of } \\
\text { different interactions in different } \\
\text { situations. }\end{array}$ & $\begin{array}{l}\text { Social Story 1: } \\
\text { "All about hugs". } \\
\text { Proxima projector } \\
\text { Laptop }\end{array}$ & $\begin{array}{l}\text { Social Story } 1 \text { was read to the } \\
\text { participants. While reading the } \\
\text { story, the trainer simultaneously } \\
\text { pointed to the pictures on the } \\
\text { PPT. In addition, each } \\
\text { participant also received her } \\
\text { own printed version of Social } \\
\text { Story } 1 .\end{array}$ & $\begin{array}{l}\text { Seven of the participants } \\
\text { preferred to follow the printed } \\
\text { version of Social Story } 1 \text {. They } \\
\text { did, however, not page through } \\
\text { the whole social story on their } \\
\text { own, but stayed with the trainer } \\
\text { turning the pages at the } \\
\text { appropriate time. Three } \\
\text { participants preferred following } \\
\text { the PPT story format. }\end{array}$ & $\begin{array}{l}\text { Although the majority of } \\
\text { participants followed in the } \\
\text { printed version, some enjoyed } \\
\text { the electronic version. } \\
\text { Therefore, it is suggested that } \\
\text { both presentation methods be } \\
\text { available in order to include } \\
\text { different learning styles. }\end{array}$ \\
\hline $\begin{array}{l}\text { To determine the } \\
\text { appropriateness of Social Story } \\
2 \text { aimed at the understanding } \\
\text { that there are happy secrets such } \\
\text { as a surprise birthday party held } \\
\text { for someone who knows } \\
\text { nothing about it. Unhappy } \\
\text { secrets are when people want to } \\
\text { take advantage of someone and } \\
\text { ask you to keep the secrets } \\
\text { about the sexual things they do } \\
\text { that can be harmful to others. }\end{array}$ & $\begin{array}{l}\text { Social Story 2: } \\
\text { "Happy and unhappy secrets" } \\
\text { Proxima projector } \\
\text { Laptop }\end{array}$ & $\begin{array}{l}\text { Social Story } 2 \text { was read to the } \\
\text { participants. While reading the } \\
\text { story, the trainer simultaneously } \\
\text { pointed to the pictures on the } \\
\text { PPT slides. In addition, each } \\
\text { caregiver also received their } \\
\text { own printed new version of } \\
\text { Social Story } 2 \text {. }\end{array}$ & $\begin{array}{l}\text { After reading Social Story } 2 \text {, the } \\
\text { trainer asked for comments } \\
\text { from the participants related to } \\
\text { the appropriateness of the } \\
\text { content. Participants agreed that } \\
\text { it was suitable for the following } \\
\text { reasons: } \\
\text { (i) the women with intellectual } \\
\text { disabilities do have difficulty in } \\
\text { being discreet in public or } \\
\text { confidential conversations; (ii) } \\
\text { women with intellectual } \\
\text { disabilities find it difficult to } \\
\text { understand the boundaries } \\
\text { between public and private } \\
\text { related topics, which is needed } \\
\text { to be socially appropriate when } \\
\text { having conversations; (iii) } \\
\text { women with intellectual } \\
\text { disabilities have difficulty with } \\
\text { being discreet related to other } \\
\text { issues beyond sexuality. }\end{array}$ & $\begin{array}{l}\text { In an attempt to teach women } \\
\text { with intellectual disabilities how } \\
\text { to be more discreet within social } \\
\text { contexts, it is often necessary to } \\
\text { enhance their understanding of } \\
\text { the concepts public and private, } \\
\text { labelling specific topics as } \\
\text { either private and confidential, } \\
\text { thereby enhancing their ability } \\
\text { to be socially appropriate within } \\
\text { their immediate environment. } \\
\text { Social Story } 2 \text { focuses on the } \\
\text { importance of social } \\
\text { appropriateness related to } \\
\text { privacy and confidentiality } \\
\text { related to "happy" and } \\
\text { "unhappy" secrets. }\end{array}$ \\
\hline $\begin{array}{l}\text { The determine the } \\
\text { appropriateness of Social Story }\end{array}$ & $\begin{array}{l}\text { Social Story 3: } \\
\text { "Different types of }\end{array}$ & $\begin{array}{l}\text { Social Story } 3 \text { was read to the } \\
\text { participants. While reading the }\end{array}$ & $\begin{array}{l}\text { Seven of the participants } \\
\text { preferred to follow the printed }\end{array}$ & $\begin{array}{l}\text { Although the majority of } \\
\text { participants followed in the }\end{array}$ \\
\hline
\end{tabular}


3 aimed at explaining how relationships are similar or different.

relationships"

Proxima projector

Laptop

Social Story 4:

"Romantic Relationships"

Proxima projector

Laptop story, the trainer simultaneously pointed to the pictures on the

PowerPoint slides. In addition, each participant also received their own printed version of

Social Story 3.

Social Story 4 was read to the participants. While reading the story, the trainer simultaneously pointed to the pictures on the PPT slides. In addition, each caregiver also received their own printed version of Social Story 4 version of Social Story 3. They did, however, not page through the whole social story on their own, but stayed with the trainer turning the pages at the appropriate time. Three participants preferred following the PPT story format.

As with Social Story 1, seven of the participants preferred to

follow the printed version of

Social Story 4, while three preferred following the PPT format. Participants commented that as a result of the women with intellectual disabilities ' isolation they have limited access to a pool of dating partners and therefore this story was inappropriate. Participants did not have the opportunity to go "on a date", making dating an abstract and foreign concept. printed version, some enjoyed the electronic version.

Therefore, it is suggested that both presentation methods be available in order to include different learning styles.

It is recommended that sections of Social Story 4 be re-written, focussing on more relevant aspects, such as their peers within the residential care facility. Furthermore, skills to distinguish between "inappropriate" and "appropriate" dating partners (conversation related) as well as "happy" and "unhappy" secrets should be included. The title of Social Story 4 should be changed to "Romantic

Relationships" rather than "Dating". 
Table 4 shows that seven participants worked at the residential care facility for at least six hours or more per day and that seven had worked for one year or more. Results from the implementation of the social stories, are shown in Table 5.

From Table 5 it is evident that all the participants found three of the four social stories appropriate and applicable. A suggestion was made that certain sections of Social Story 4 should be re-written to be more applicable to the specific context. This might be attributed to the fact that the caregivers were from residential care facilities and thus related the stories to their own context, as "dating" is not allowed at this particular context. Hence it was decided to re-write Social Story 4 to be more inclusive, and to reflect romantic relationships in a broader sense.

Following the training, the participants were asked to provide a training evaluation feedback. All stated that they found the training applicable and useful, and that they would appreciate further training on the topic of sexuality and relationships. Five participants specified that they particularly enjoyed the "All about hugs" social story (Appendix A), with one participant stating "I never new that u can ask a person to give him/her a hug" (sic).

\section{Critical evaluation of the research}

The three phased research design involving a systematic review of the literature (Phase 1) followed by a focus group of women with intellectual disability (Phase 2), that resulted in a custom-written social is a strength. This was further enhanced by training a group of caregivers to determine the appropriateness and suitability of the stories before training the women themselves (Phase 3), heightening the appropriateness of the stories. Furthermore, the stories are written in easy language, and accompanied by pictures, which makes it appropriate for use by individuals with low literacy levels.

Obtaining ethics approval and informed consent for the execution of this study was challenging. At first, the researcher tried to obtain consent from the parents or legal guardians of women with intellectual disabilities but this was problematic for various reasons. Some parents/guardians thought that sexuality education was inappropriate for their daughter with intellectual disability, some parents were elderly and had no interest in the importance of the topic, some expressed logistical concerns, stating that they could not afford to drive to the facility to attend an information session, and some refused without providing a reason. Hence it was decided to train a secondary stakeholder group (namely caregivers) before commencing with training women 
with intellectual disabilities themselves. This had the added benefit of heightening the applicability and relevance of the study as described earlier.

Challenges were also experienced in the recruitment of facilities to participate in this research. The directors at many adult facilities stated that they regarded sexuality training as inappropriate or redundant. They expressed a fear that sexuality and relationship training would result in an increase in sexuality behaviour in women with intellectual disability - a behaviour they were actively trying to discourage and suppress. Some directors were in denial about any sexual activity in their facility and claimed that the women with intellectual disability were "asexual" and that the training would thus be redundant. These findings showcase the misconceptions and myths related to the sexuality of women with intellectual disability.

Therefore, the development of an advocacy program that could precede this training to heighten awareness of the importance of sexuality education for women with intellectual disability, and dispel common myths and misconceptions, is recommended. A recommendation was made that this training should be replicated with women with intellectual disabilities themselves as participants, as this would show the direct impact of the use of social stories with the primary stakeholder group and not with the secondary stakeholder group.

\section{Conclusion}

The main clinical implication of this research is that social stories can be used successfully in the inservice sexuality education of caregivers at adult care facilities with the aim of explaining complex concepts related to sexuality and relationships in an easy, understandable manner in order to make it applicable to women with intellectual disability. The provision of sexuality education on an on-going basis and the promotion of positive attitudes towards appropriate expression of sexuality are critical to the realisation of sexual autonomy for women with intellectual disabilities.

\section{REFERENCES}

Ali, S., \& Frederickson, N. (2006). Investigating the evidence base of social stories. Educational Psychology in Practice, 22(4), 355-377.

Bernert, D.J. (2011). Sexuality and disability in the lives of women with intellectual disabilities. Sexuality and Disability, 29, 129-141. 
Bleazard, A. V. (2010). Sexuality and intellectual disability: Perspectives of young women with intellectual disability. (Unpublished doctoral thesis). Stellenbosch University, Stellenbosch, South Africa.

Boehning, A. (2006). Sex education for students with disabilities. Indiana University Scholar Works. Law and Disorder, (1) 59-66.

Chan, J.M., \& O'Reilly, M.F. (2008). A social stories intervention package for students with autism in inclusive classroom settings. Journal of Applied Behaviour Analysis, 41(3), 405-409.

Couwenhoven, T.C. (2007). Teaching children with Down Syndrome about their bodies, boundaries and sexuality. Bethesda, MA: Woodbine House.

Deeley, S. (2002). Professional ideology and learning disability: An analysis of internal conflict. Disability and Society, 17(1), 19-33.

Del Valle, P.R., McEachern, A.G., \& Chambers, H.D. (2001). Using social stories with autistic children. Journal of Poetry Therapy, 14(4), 187-197.

Den Hoogh, A.H.B., \& Den Hartog, D.N. (2008). Ethical and despotic leadership, relationships with leader's social responsibility, top management team effectiveness and subordinates' optimism: A multi-method study. The Leadership Quarterly, 19, 297-311

Evans, D.S., McGuire, B.E., Healy, E., \& Carley, S.N. (2009). Sexuality and personal relationships for people with an intellectual disability. Part II: staff and family carer perspectives. Journal of Intellectual Disability Research, 53(11), 913-921.

Fitzgerald, C., \& Withers, P. (2011). I don't know what a proper woman means: What women with intellectual disabilities think about sex, sexuality and themselves. British Journal of Learning Disabilities, 41, 5-12.

Gerhardt, S. (2006). Why love matters: How affection shapes a baby's brain. Infant observation, 9(3), 305-309.

Gougeon, N.A. (2009). Sexuality education for students with intellectual disabilities, a critical pedagogical approach: Outing the ignored curriculum. Sex Education, 9(3), 277-291.

Graetz, J.E., Mastropieri, M.A., \& Scruggs, T.E. (2009). Decreasing inappropriate behaviours for adolescents with autism spectrum disorders using modified social stories. Education and Training In Developmental Disabilities, 44(1), 91-104.

Gray, C. (1995). Your concerns result in a social story ratio: A closer look at directive sentences. Access Express, 4, 4-5.

Gray, C. (1997). My Social Stories Book. (Illustrated edition). Retrieved from http://www.goodreads.com/book/show/696691.My_Social_Stories_Book

Gray, C. (2000). The New Social Story Book. (Illustrated edition). Arlington, TX: Future Horizons, Inc.

Gray, C. (2003). Social stories. Retrieved from http://www.thegraycenter.org/social-stories/how-to-writesocialstories?tmpl=compone

Hanna, R., \& Rogovsky, B. (1991). Women with disabilities: Two handicaps plus. Disability Handicap and Society, 6(1), 49-63.

Kalyva, E., \& Agaliotis, I. (2009). Can social stories enhance the interpersonal conflict resolution skills of children with Learning Disabilities? Research in Development Disabilities, (30)1, 192-202.

Klett, L.S., \& Turan, T. (2012). Generalized social effects of social stories with task analysis for teaching menstrual care to three young girls with autism. Sexuality and Disability, 30(3), 319-336. 
Lafferty, A., McConkey, R., \& Taggart, L. (2013). Beyond friendship: The nature and meaning of close personal relationships as perceived by people with learning disabilities, Disability and Society, 28(8), 1074-1088.

Mancil, G.R., Haydon, T., \& Whitby, P. (2009). Differentiated effects of two social story ${ }^{\mathrm{TM}}$ formats, paper versus computer assisted on inappropriate behaviour of children with autism spectrum disorders. Focus on Autism and Other Developmental Disabilities, 204, 205-215.

Miodrag, N. (2004). An exploration of a socio-sexual education program for individuals with developmental disabilities: Changes in knowledge and attitudes. (Unpublished master's dissertation). Concordia University, Montreal, Canada.

Morales, G.E., Lopez, E.O., \& Mullet, E. (2011). Acceptability of sexual relationships among people with learning disabilities: Family and professional caregivers' views in Mexico. Sexuality and Disability, 29, 165-174.

Moyes, R.A. (2001). Incorporating Social Goals in the Classroom: A guide for teachers and parents of children with high-functioning Autism and Asperger Syndrome. London, UK: Jessica Kingsley Publishers.

Ozdemir, S. (2008). The effectiveness of social stories on decreasing disruptive behaviours of children with autism: Three case studies. Journal of Autism and Developmental Disorder, 38, 1689-1696.

Pettigrew, J. D. C. (1998). Effects of the modelling of verbal and non-verbal procedures for interactions with peers through social stories and scaffolded activities on the social competence of 3-and 4-year-old children with specific language impairments. (Unpublished doctoral thesis). Texas Woman's University, Denton, TX, US.

Quilty, K.M. (2007). Teaching paraprofessionals how to write and implement social stories for students with autism spectrum disorders. Remedial and Special Education, 28(3), 182-189.

Quimbach, L.M., Lincoln, A.J., Feinberg-Gizzo, M.J., Ingersoll, B.R., \& Andrews, S.M. (2009). Social stories: Mechanisms of effectiveness in increasing game play skills in children diagnosed with autism spectrum disorder using a pretest posttest repeated measures randomized control group design. Journal of Autism and Developmental Disorders, 39, 299-321.

Rathbone, L. (2015). The effect of a sexuality training programme on the knowledge and attitudes of caregivers working with women with intellectual disabilities who live in residential care facilities: a social story approach. (Unpublished doctoral thesis). University of Pretoria, Pretoria, South Africa.

Szollos, A.A., \& McCabe, M.P. (1995). The sexuality of people with mild intellectual disability: Perceptions of clients and caregivers. Australia and New Zealand Journal of Developmental Disabilities, 20(3), 205 222.

Tarnai, B., \& Wolfe, P.S. (2008). Social stories for sexuality education for persons with autism/pervasive developmental disorder. Sexual Disabilities, 26, 29-36.

Toplis, R., \& Hadwin, J.A. (2006). Using social stories to change problematic lunchtime behaviour in school. Educational Psychology in Practice, Theory, 22(1), 53-67.

Wang, P., \& Spillane, A. (2009). Evidence-based social skills interventions for children with autism: A meta analysis. Education and Training in Development, 44(3), 318-342. 


\section{Appendix A :}

Social story 1 : “All About Hugs” (Rathbone, 2015)

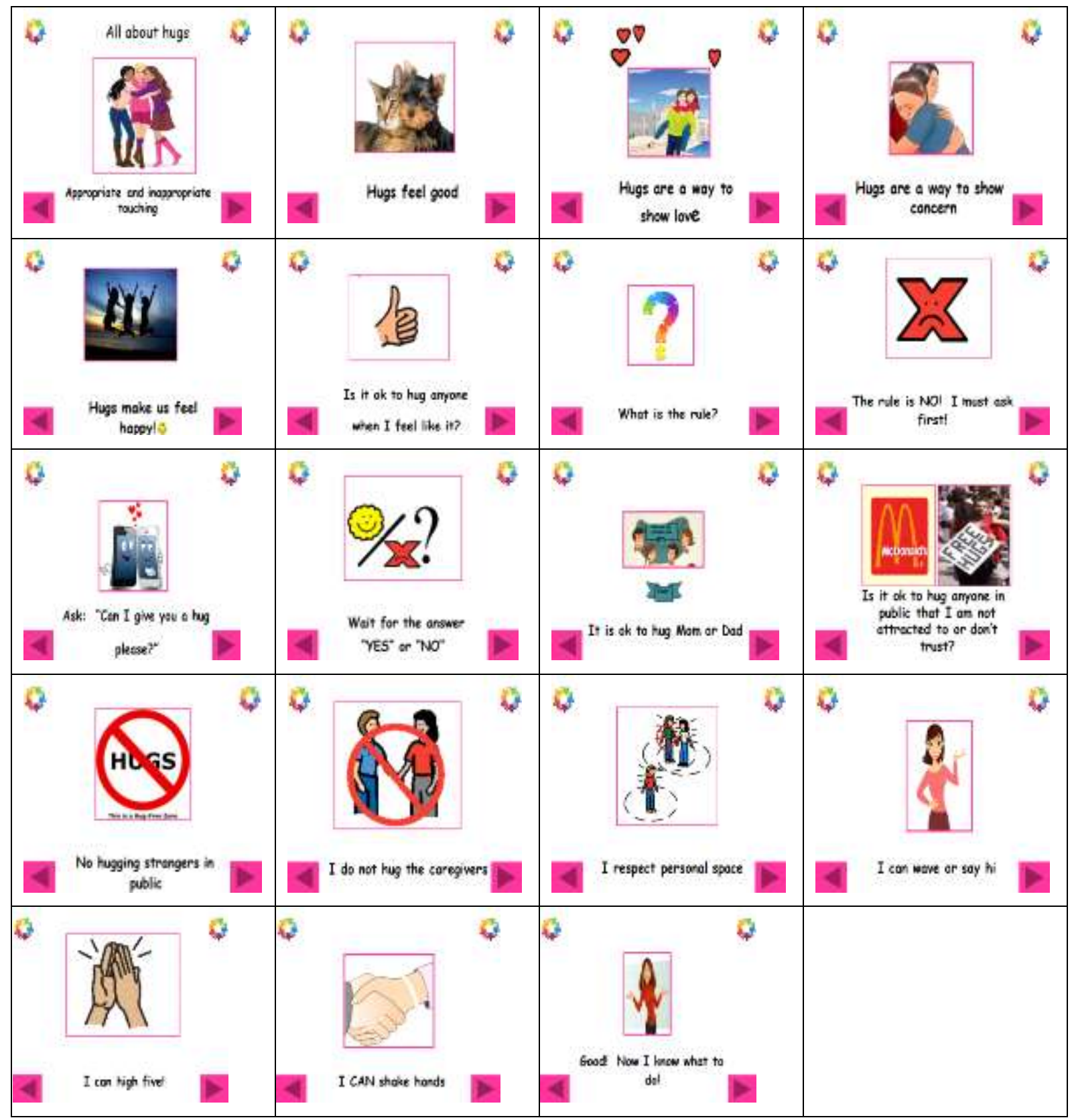

